\title{
Cairndene: Leading the Project Management Professional Development
}

\author{
Georgia Brown \\ Cairndene Ltd, United Kingdom
}

\begin{abstract}
:
This paper aims to evaluate the arguments regarding implementing the concept of industry-wide certification of training programmes in the oil and gas sector. The main emphasis is being made on the demand and challenges in implementing the industrywide evaluation of training. The paper introduces an accessible framework of credit rating, which would provide a robust, internationally recognised, quality assured credit system for industry relevant courses.
\end{abstract}

This case study analyses the industry-wide demand for strong internal planning resources to coordinate project activities and introduces the proposition of focused credit-rated training solutions combined with work-based mentoring to support in-house skills development by North Sea operators.

Paper type: Case study

Keywords: Engineering, Project Management, Professional Development, Oil and Gas Industry 


\section{Introduction}

The role of projects and their management is difficult to underestimate in any industry and in the oil and gas industry in particular. In order to deal effectively with the increasing magnitude of effective project management, organisations pursue the technological (e.g. software based) and/or training centred solutions. Davies et al (2011) maintain that complementing or in some cases replacing traditional organisational structures with project-based systems is a necessity of today's business environment. Any structural change needs to be supplemented by an adequate training solution to ensure the synchronisation between technology, people and organisational objectives. Organising and implementing such alignment of different actors is not without challenges. Johnson (2009) indicates that despite the commitment of enormous organisational efforts and resources, $68 \%$ of projects fail due to many reasons that can be summarised using the term 'complexity' (Janssen et al, 2015).

To what extent can the complexity of project-based activities be reliably minimised? This is a key question for many firms in the oil and gas industry providing project management supporting services. The solution however is far from obvious or straightforward. Cairndene Ltd, an engineering and project planning consultancy firm, has found its formula in ensuring effective project management and planning solutions.

\section{Building in-house project planning expertise}

Across the energy industry, getting project management and planning right can save time, money and effort. But rather than planning expertise being developed in-house, it tends to be a skill expensively bought in - often with disappointing and costly results.

Cairndene, as a training provider, has utilised its years of experience in the oil and gas sector to identify the learning needs, develop objectives for an effective learning programme and create a business case for the identified skills gap. Cairndene addresses this skills gap with its work-based course in Understanding Project Planning \& Scheduled Risk, accredited by the Oil \& Gas Academy of Scotland to the Scottish Credit and Qualifications Framework (SCQF) internationally recognised credit rating system.

\section{Project planning and management}

\subsection{Industry view}

Many companies do not have a strong internal planning resource and have to rely heavily on external project control contractors but there is a growing awareness within the industry that many of these external 'experts' having limited suitability for the factual issues industry players are facing. As a result of this misfit, oil and gas companies may lose time, money and credibility in their attempts to battle with daily challenges.

Building up and recognising in-house project planning skills is one of the ways forward, both for industry strength and to ensure employees' professional development. Cairndene, drawing on its engineering and project planning expertise, offers focused

International Journal of Management and Applied Research, 2015, Vol. 2, No. 3 
OGAS (SCQF) credit-rated training solutions combined with work-based mentoring and support to ensure in-house skills development.

\subsection{Course details}

Using a combination of training and on-going coaching, Cairndene can provide project managers and planners with the knowledge they need, along with the skills to use the industry standard software and tools. Modules include Fundamental Project Planning, Advanced Project Planning and Managing Project Schedule Risk.

At Cairndene, "What we do differently is that our training focuses more on methodology. It teaches in such a way that students can plan and develop projects irrespective of the software they are using - or even without software at all. With other courses they learn how to use the software; they don't learn how to plan."

As these courses are to be accredited by the OGAS-enabled SCQF internationally recognised credit rating system, individuals can use them as a reliable route to further their formal qualifications in the further and higher education sectors and the industry as a whole will benefit from the increased opportunity for continued professional development (CPD).

\subsection{Credit-rated course benefits}

The benefits of the OGAS-enabled SCQF internationally recognised credit rating system are in establishing transparent relationships between qualifications, with learners being able to make the most of credit transfer opportunities and progression routes (SQA, 2015) in developing their own qualifications portfolio. The companies who commission people to take these programmes, because of the accreditation, will be able to place higher levels of confidence in the ability of the training or educational activity to deliver effectively the objectives of the course (Rattray, 2015).

Benefits for the employer include:

- Strong in-house project controls skills - develop your in-house expertise, reducing your reliance on expensive external contractors

- International recognition of staff skills, through SCQF credit-rated training demonstrate the quality and competence of your planners

- Employee retention - keep expert workers who otherwise may be looking to change roles

- Improved staff motivation - engage staff in a career-enhancing, credit-rated training programme

- Flexible learning - with work-based learning, the need for day release is greatly reduced

- Improved company performance - better planning helps you make better decisions

- Cost-saving - more cost-effective product or service delivery

- Give employees potential access to and full/partial credit towards existing FE/HE provision - staff might not have considered such development without this option

International Journal of Management and Applied Research, 2015, Vol. 2, No. 3 
Benefits for the employee comprise of:

- In-depth knowledge - training on the theory of planning and project controls as well as the Primavera system

- Incentive to fully engage with career-enhancing training and education - with clear routes to tertiary education

- Enhanced job satisfaction - with greater skills, knowledge and ability

- Greater involvement - better plans mean better understanding of company objectives and more staff involvement

- Improved career prospects via internal promotion

- Alternative route into tertiary education

\section{Conclusion}

The approach advocated in this case study is in line with current research in the fields of engineering and project management, promoting in-house professional development and supporting non-traditional learning initiatives (Winter et al, 2006).

\section{References}

1. Davies, A., Brady, T., Prencipe, A. and Hobday, M. (2011), "Innovation in complex products and systems: implications for project-based organizing", in Cattani, G.; Ferriani, S.; Frederiksen, L. and Täube, F. (ed.) Advances in Strategic Management, Vol. 28, UK: Emerald Group Publishing Limited, pp.3 - 26

2. Janssen, M., Voort, H. And Veenstra, A. (2015), "Failure of large transformation projects from the viewpoint of complex adaptive systems: Management principles for dealing with project dynamics", Information Systems Frontiers, Vol. 17, No. 1, pp 15-29. https://doi.org/10.1007/s10796-014-9511-8

3. Johnson, J. (2009), Chaos summary: 10 laws of chaos, Boston: The Standish Group.

4. Rattray, R. (2015), "Considerations for Industry-Wide Certification of Training in the Oil and Gas Sector of Scotland", International Journal of Management and Applied Research, Vol. 2, No. 3, pp. 102-107. https://doi.org/10.18646/2056.22.15009

5. Winter, M., Smith, C., Morris, P. and Cicmil, S. (2006), "Directions for future research in project management: the main findings of a UK government funded research network", International Journal of Project Management, Vol. 24, No. 8, pp. 638-649. https://doi.org/10.1016/j.ijproman.2006.08.009 